\title{
The effect of topical $0.05 \%$ cyclosporine on recurrence following pterygium surgery
}

This article was published in the following Dove Press journal:

Clinical Ophthalmology

28 June 2011

Number of times this article has been viewed

Ece Turan-Vural'

Banu Torun-Acar'

S Argun Kivanc ${ }^{2}$

Suphi Acar'

'Haydarpașa Numune Education and Research Hospital, Ophthalmology Clinic, Istanbul, Turkey; ${ }^{2}$ Umranıye Education and Research Hospital, Ophthalmology Clinic, Istanbul, Turkey

Correspondence: Ece Turan-Vura Haydarpașa Egitim ve Arastırma Hastanesi Tibbiye Caddesi No:40, 34668 Uskudar, Istanbul, Turkey

$\mathrm{Tel}+905054004628$

Fax +90 2163377877

Email dreceturan76@yahoo.com
Purpose: To investigate the role of postoperative topical $0.05 \%$ cyclosporine A (CsA) eye drops (Restasis ${ }^{\circledR}$, Allergan Pharmaceutical) in the prevention of recurrence among patients with primary pterygium treated with bare-sclera technique.

Methods: In this prospective randomized controlled study, 36 eyes (34 patients) with primary pterygium were randomized into two groups: Group I comprised 18 eyes (18 patients), and Group II comprised 18 eyes (16 patients). Bare sclera technique was performed in both groups. In Group I, $0.05 \%$ CsA was administered postoperatively at 6-hour intervals for 6 months, and Group II did not receive any cyclosporine treatment. The patients were assessed for recurrence, side effects, and complications at postoperative 1 and 7 days as well as each month during the following year. Conjunctival advances which showed a limbus higher than $1 \mathrm{~mm}$ were recognized as recurrence.

Results: Recurrence occurred in four patients (22.2\%) in Group I and in eight (44.4\%) patients in Group II.

Conclusion: Postoperative application of low-dose CsA can be effective for preventing recurrences after primary pterygium surgery.

Keywords: primary pterygium, cyclosporine A, bare sclera

\section{Introduction}

Pterygium is a common ocular surface disease characterized by tissue remodeling, cellular proliferation, neovascularization, and inflammation. ${ }^{1,2}$ A stromal overgrowth of fibroblast and blood vessels are accompanied by an inflammatory cell infiltrate and abnormal extracellular matrix accumulation. ${ }^{3-6}$ Although several hypotheses have been associated with its etiology, its pathology still remains to be explained. Secretion of proinflammatory cytokines such as interleukin (IL)-1, IL-6, IL-8, and tumor necrosis factor (TNF)- $\alpha$ secondary to chronic ultraviolet (UV) radiation, is a widely recognized etiological factor in pathogenesis of this lesion. ${ }^{6,7}$ These cytokines can stimulate proliferation of cultured Tenon's capsule fibroblasts and induce expression of matrix metalloproteinases in cultured pterygium; specifically, IL-1 plays an important role in the development process of pterygium. ${ }^{6,7}$

The vascular endothelial growth factor (VEGF) family, which is known to have a role in angiogenesis, has been shown to exhibit an increase in pterygium epithelium and vascular endothelium. ${ }^{8-13}$ VEGF is believed to be stimulated by a mediation of TNF- $\alpha$ through UVB (ultraviolet B) induction. ${ }^{14}$

Cyclosporine A (CsA) shows a selective effect against T-helper cells and prevents the synthesis and secretion of ILs. ${ }^{16} \mathrm{CsA}$ has also been shown to block angiogenic 
factors induced by VEGF. ${ }^{15-17}$ Based on these studies, we thought CsA might have an effective role on treatment of pterygium.

The aim of this study was to investigate the influence of postoperative topical CsA use on recurrence.

\section{Method}

This study was a prospective randomized controlled study on 36 consecutive eyes of primary pterygium. Written informed consent was obtained from all the patients. All pterygia were located nasally. Ocular diseases and surgical history of the patients are shown in Table 1 . The patients were randomized into two groups: 18 eyes of 18 patients were included in Group I, and 18 eyes of 16 patients were included in Group II. Female/male ratio was the same in both groups (nine female, nine male).

The inclusion criteria were:

- Diagnosis of primary pterygium

- Pterygium size $\geq 2 \mathrm{~mm}$ (the horizontal length of the tissue from limbus to cornea was measured by slit lamp biomicroscopy)

- Ocular discomfort refractory to medical treatment

- Visual loss induced by pterygium.

Patients who had a recurrent pterygium or allergy to topical CsA, and those who were pregnant, were excluded from the study.

Bare sclera method was performed in both groups. Surgical procedures were performed under local anesthesia using an operation microscope. The pterygium head was taken off the cornea by blunt dissection with a crescent knife. The body of pterygium was dissected and excised with Westcott scissors. Minimal cautery was used to maintain hemostasis. The conjunctiva was closed together with a size $8 / 0$ vicryl suture, leaving a 4-mm bare sclera. The eyes were closed with a rondel after the application of antibiotic ointment. In all of the patients, antibiotic drops were given for 15 days and steroid drops were given for 1 month. In Group I, 0.05\% CsA (Restasis ${ }^{\circledR}$, Allergan Pharmaceutical) was administered postoperatively at 6-hour intervals for 6 months. In Group II,

Table I Ocular diseases and surgical history of the patients

\begin{tabular}{ll}
\hline Disease/surgery & Number of cases $(\mathbf{n}=\mathbf{3 4})$ \\
\hline Glaucoma & 10 \\
Diabetic retinopathy & 6 \\
Trabeculectomy & 6 \\
Vitreoretinal surgery & 9 \\
Implantation of Ahmed glaucoma valve & $\mathrm{I}$ \\
Scleral fixation intraocular lens & 2 \\
\hline
\end{tabular}

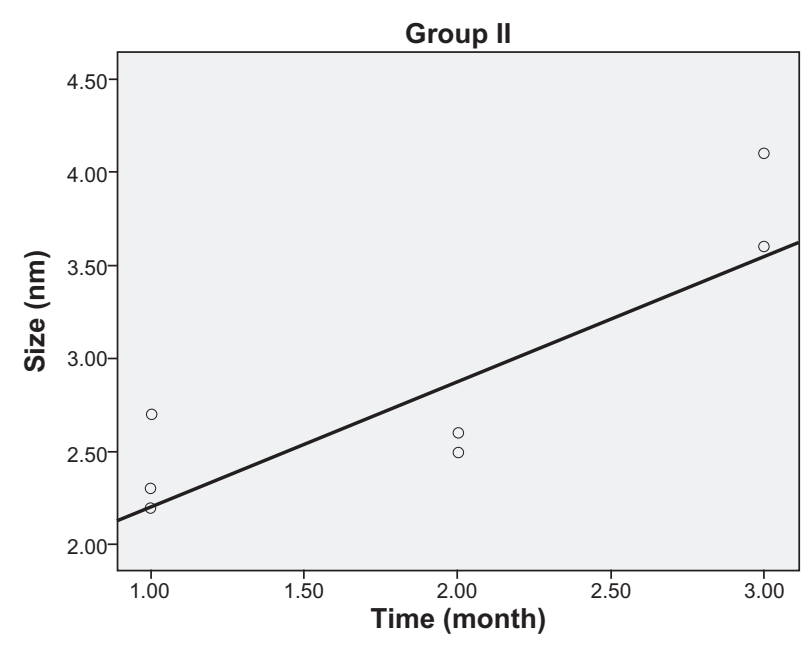

Figure I The relationship between pterygium size and recurrence time in Group II.

patients did not receive CsA. All patients were followed up at postoperative 1 day, 7 days, and then every month. Minimum duration of the follow-up periods was 12 months. In each follow-up, patients were assessed for recurrence and postoperative complications such as persistent corneal defect, infection, scleral melting, and drop intolerance. The recurrence was defined as fibrovascular tissue invading the cornea $\geq 1 \mathrm{~mm}) .{ }^{17,18}$

\section{Statistical analyses}

NCSS (Number Cruncher Statistical System) 2007 and PASS

(Power Analysis and Sample Size) 2008 statistical software (NCSS, Kaysville, UT) was used for the statistical analyses. The study data were expressed by definitive statistics (mean, standard deviation, median). Quantitative data were compared by independent samples $t$-test and Mann-Whitney U test. The

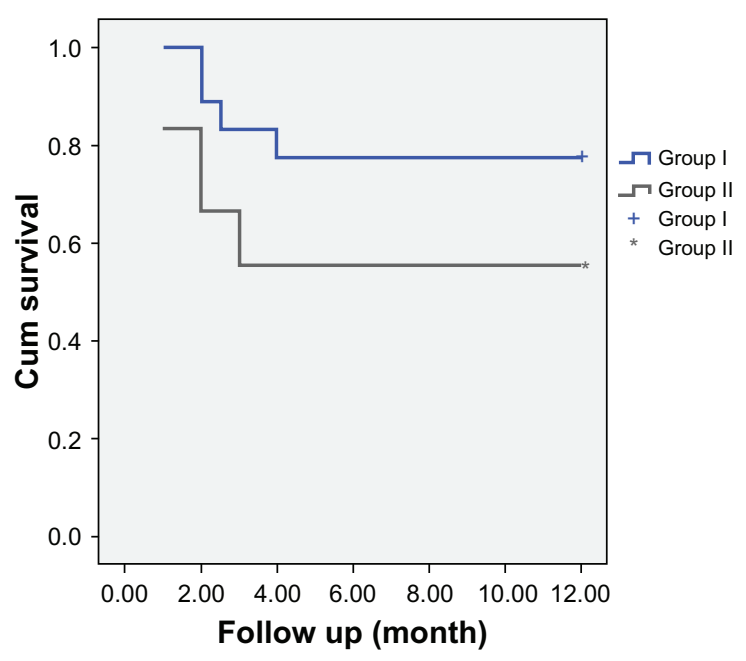

Figure 2 Distribution of the recurrence-free follow-up times. 
Table 2 Evaluations relative to the groups

\begin{tabular}{|c|c|c|c|c|}
\hline & & \multirow{2}{*}{$\begin{array}{l}\text { Group I } \\
\text { Mean } \pm \text { SD }\end{array}$} & \multirow{2}{*}{$\begin{array}{l}\text { Group II } \\
\text { Mean } \pm \text { SD }\end{array}$} & \multirow[t]{2}{*}{$P a$} \\
\hline & & & & \\
\hline \multicolumn{2}{|l|}{ Age (year) } & $57.05 \pm 11.65$ & $53.27 \pm 10.88$ & 0.322 \\
\hline \multicolumn{2}{|c|}{$\begin{array}{l}\text { Pterygium size } \\
(\mathrm{mm})\end{array}$} & $3.00 \pm 0.57$ & $2.73 \pm 0.61$ & 0.169 \\
\hline \multicolumn{2}{|c|}{ Recurrence time } & $2.62 \pm 0.95$ & $1.87 \pm 0.83$ & 0.213 \\
\hline & & n (\%) & n (\%) & $P^{\mathrm{b}}$ \\
\hline \multirow[t]{2}{*}{ Gender } & Female & $9(50.0)$ & $9(50.0)$ & 1.000 \\
\hline & Male & $9(50.0)$ & $9(50.0)$ & \\
\hline \multirow[t]{2}{*}{ Recurrence } & Yes & $4(22.2)$ & $8(44.4)$ & 0.157 \\
\hline & No & $14(77.8)$ & $10(55.6)$ & \\
\hline
\end{tabular}

Notes: Independent samples $t$-test; ${ }^{\text {b}}$ Chi-square test; 'Mann-Whitney $U$ test. Abbreviation: SD, standard deviation.

relationship between the pterygium size and the recurrence time was evaluated by Spearman's rank correlation analysis. Recurrence-free survival time was evaluated by KaplanMeier survival analysis. Categorical data were evaluated by Chi-square test. $P<0.05$ was recognized as statistically significant.

\section{Results}

Our study was performed on 36 eyes in total (18 eyes in Group I and 18 eyes in Group II). None of the groups demonstrated scleral thinning, necrosis, or any other visually significant complication. The CsA group (Group I) showed no adverse reaction other than a mild burning sensation and irritation at the time of the application. There was no statistically significant difference between the groups with regard to age $(P>0.05)$. Mean age was $57.05 \pm 11.65$ in Group I and $53.27 \pm 10.88$ in Group II. No statistically significant difference was determined between the groups in terms of pterygium size $(P>0.05)$. Mean pterygium size was $3.00 \pm 0.57 \mathrm{~mm}$ in Group I and $2.73 \pm 0.61 \mathrm{~mm}$ in Group II. We observed no statistically significant difference between the recurrence times of the groups $(P>0.05)$. Mean recurrence time was $2.62 \pm 0.95$ months in Group I and $1.87 \pm 0.83$ months in Group II. There was no statistically significant difference between the groups relative to gender distribution $(P>0.05)$. Although recurrence rate was higher

Table 3 Evaluation of the pterygium sizes relative to recurrence rates

\begin{tabular}{lllll}
\hline Recurrence & \multicolumn{2}{l}{ Pterygium size $(\mathbf{m m})$} & $\boldsymbol{P}$ \\
\cline { 2 - 4 } & $\mathbf{n}$ & Mean \pm SD & Median & \\
\hline$(+)$ & 12 & $2.73 \pm 0.61$ & 2.55 & 0.305 \\
$(-)$ & 24 & $2.93 \pm 0.59$ & 2.90 & \\
\hline
\end{tabular}

Note: Independent samples $t$-test was applied.
Table 4 The relationship between the pterygium size and the recurrence time

\begin{tabular}{lll}
\hline & $\begin{array}{l}\text { Pterygium size } \\
(\mathbf{m m})\end{array}$ & $\begin{array}{l}\text { Recurrence time } \\
(\text { months })\end{array}$ \\
\cline { 2 - 2 } & $\mathbf{r}^{\mathbf{a}}$ & $\mathbf{P}$ \\
\hline Group I $(\mathrm{n}=4)$ & -0.632 & 0.368 \\
Group II $(\mathrm{n}=8)$ & 0.684 & $0.013^{\mathrm{b}}$ \\
Total $(\mathrm{n}=\mathrm{I} 2)$ & 0.343 & 0.276 \\
\hline
\end{tabular}

Notes: aSpearman's correlation; ${ }^{\mathrm{p} P}<0.05$.

in Group II than in Group I, the difference was not statistically significant $(P>0.05)$ Table 2 . No statistically significant difference was determined between the cases with and without recurrence in terms of pterygium size $(P>0.05)$ Table 3.

In view of all cases with recurrence, although pterygium size and recurrence time showed a considerable positive correlation, it was not statistically significant $(r=0.343$; $P>0.05)$ Table 4. In Group I, pterygium size and recurrence displayed a negative correlation in four cases with recurrence; however, due to the low number of cases, it was not found to be statistically significant $(P>0.05)$. In Group II, pterygium size and recurrence showed a significant positive correlation (68.4\%) in eight cases with recurrence (pterygium size elevated parallel to the increases in recurrence time).

In Group I, while four cases exhibited recurrence Figure 1, 14 (77.8\%) did not show recurrence, and the mean recurrence-free follow-up time was $9.92 \pm 0.92$ months. In Group II, while eight cases exhibited recurrence, 10 $(55.6 \%)$ cases did not show recurrence, and the mean recurrence-free follow-up time was $7.50 \pm 1.19$ months Table 5. Recurrence-free survival rates were evaluated by logrank test and no statistically significant difference was determined between the 12-month survival rates $(P=0.130$, $P>0.05)$ Figure 2.

\section{Discussion}

Previously, pterygium was recognized as a degenerative condition; recently, as a result of the latest studies, it is thought to be a growth disorder, and mainly proliferative factors are investigated for revealing the true etiopathogenesis. ${ }^{5,17}$ Therefore, surgical treatments aim to replace limbal stem cells, whereas adjuvant therapies target preventing proliferation and angiogenesis. Despite those studies, a definitive treatment method which shows no recurrence, along with the least degree of complications, has yet to be found. The most widely recognized proposal for pathogenesis is that UV increases release of certain multifactorial cytokines, IL-6 and IL-8, from pterygium epithelium, which leads to the initialization of 
Table 5 Survival rate during recurrence-free follow-up time

\begin{tabular}{llllll}
\hline Group & $\mathbf{N}$ & $\begin{array}{l}\text { Recurrence } \\
(+)\end{array}$ & $\begin{array}{l}\text { Recurrence } \\
(-)\end{array}$ & $\begin{array}{l}\text { Survival rate without } \\
\text { recurrence (\%) }\end{array}$ & $\begin{array}{l}\text { Mean recurrence-free } \\
\text { follow-up time (months) }\end{array}$ \\
\hline Group I & 18 & 4 & 14 & 77.8 & $9.92 \pm 0.92$ \\
Group II & 18 & 8 & 10 & 55.6 & $7.50 \pm 1.19$ \\
\hline
\end{tabular}

Note: Kaplan-Meier analysis.

neovascularization and chronic inflammation..$^{5-7}$ IL-6 has been shown to increase angiogenesis via VEGF induction. ${ }^{19}$ Despite considerable contribution of UV and environmental factors, occurrence of pterygium is varied in people living in the same environment. Hypersensitivity is a powerful factor in pathogenesis, and the amount of immunoglobulin $\mathrm{E}$ ( $\operatorname{IgE}$ ) has been found to exhibit an elevated level in pterygium tissue ${ }^{19} \mathrm{IgE}$ rise leads to release of cytokines, causing thrombocyte aggregation, which causes release of growth factors leading to epithelium proliferation. Although previous studies demonstrate that $\mathrm{T}$ lymphocytes are rarely identified in conjunctiva, they are found to be in elevated levels in pterygium tissue. ${ }^{19}$ All those data show the importance of T-lymphocyte-mediated strong cellular immunity in pterygium pathogenesis. CsA selectively suppresses functions of T-helper lymphocytes and production of both inflammatory cytokines and inflammatory mediators. ${ }^{20,21}$ In animal studies, it has been shown to suppress IgE production in a T-cell-dependent manner and inhibit histamine release from basophil and mast cells. ${ }^{21}$ In vivo and in vitro studies have showed that CsA inhibits angiogenesis triggered by VEGF. We believed that inhibiting all those paths with CsA, which are thought to have a role over pterygium pathogenesis, might be effective in preventing recurrence. ${ }^{22} \mathrm{CsA}$ $0.05 \%$ is found to be effective in inhibiting the proliferation in Tenon's capsule fibroblasts. ${ }^{23}$ In a study similar to ours, thiotepa and cyclosporine have been compared following pterygium surgery and CsA was found to be significantly more effective than thiotepa. ${ }^{24}$

The recurrence rate was $44.4 \%$ for bare sclera technique and $22.2 \%$ for bare sclera technique + topical $0.05 \%$ CsA. None of our cases demonstrated a serious complication. Moreover, recurrence rate was observed to decrease. Our study group was comprised of glaucoma or diabetic retinopathy patients who had a history of vitreoretinal or glaucoma surgery in whom we could not perform a treatment with conjunctival or limbal autograft. Therefore, we were unable to deliver mitomycin and other adjuvant therapies and thus had the chance to evaluate efficacy of CsA in a surgical procedure associated with high recurrence rates. Because of this study design, we believe that our study obtained more reliable results on the effects of CsA over recurrence rates.

Similar studies have been performed by using conjunctival autografts. Tok et al used CsA following primary excision in primary pterygium cases, and the recurrence rate was determined to be $12.9 \% .{ }^{25}$ In a study by Aydin et al, CsA was found to be effective in reducing recurrence and preventing postoperative pain and complications. ${ }^{26}$ However, Aydin et al used CsA after applying limbal conjunctival autograft and observed a recurrence rate of 3.4\%. Ibáñez et al preferred to apply the combination of mitomycin + conjunctival autograft and determined a recurrence rate of $7.5 \%{ }^{27}$ In our study, the recurrence rate was $22.2 \%$.

While our study appears to be similar with that of Tok et al our recurrence rate is higher. We believe that by applying more effective surgical techniques, such as conjunctival autograft and limbal autograft, we could have obtained better results. Moreover, although a remarkable decrease was observed in the recurrence rate of the patient group, the results were not statistically significant due to the low number of cases. However, since it is known to be a safe method, it can be performed among patients with a history of major surgery or in candidates of such surgeries. In conclusion, we believe that more effective results can be achieved by using topical CsA at higher doses.

\section{Disclosure}

This study was performed at Umraniye Education and Research Hospital, Ophthalmology Clinic, Istanbul, Turkey. The study was not presented at any meeting. There was no public or private financial support. None of the authors has a financial or proprietary interest in a product, method, or material used in the study.

\section{References}

1. Coroneo MT, Girolamo N, Wakefield D. The pathogenesis of pterygia. Curr Opin Ophthalmol. 1999;10:282-288.

2. Hill JC, Maske R. Pathogenesis of pterygium. Eye. 1989;3:218-226.

3. Cameron ME. Histology of pterygium: an electron microscopic study. Br J Ophtalmol. 1983;67:604-608.

4. Chan CM, Liu YP, Tan DT. Ocular surface changes in pterygium. Cornea. 2002;21:38-42.

5. Wang IJ, Lai WT, Liou SW. Impression cytology of pterygium. J Ocular Pharmacol Therap. 2000;16:519-528. 
6. Di Giriloma N, Chui J, Coreneo MT, Wakefield D. Pathogenesis of pterygia: role of cytokines, growth factors, and matrix metalloproteinases. Prog Retin Eye Res. 2004;23(2):195-289.

7. Girolama ND, Kumar RK, Cornea MT, Wakefield D. UVB. Mediated indication of interleukin- 6 and 8 in pterigia and cultured human pterigium epithelial cells. Inves Opthalmol Vis Sci. 2002;143(119):3430-3437.

8. Dushku N, Reid TW. P53 expression in altered limbal basal cells of pingueculae, pterygia, and limbal tumors. Curr Eye Res. 1997;16(12): 1179-1192.

9. Tan DT, Tang WY, Liu YP, Goh HS, Smith DR. Apoptosis and apoptosis related gene expression in normal conjunctiva and pterygium. Br J Ophthalmol. 2000;84(2):212-216.

10. Weinstein O, Rosenthal G, Zirkin H, Monos T, Lifshitz T, Argov S. Overexpression of p53 tumor suppressor gene in pterygia. Eye. 2002; 16(5):619-621.

11. Lee DH, Cho HJ, Kim JT, Choi JS, Joo CK. Expression of vascular endothelial growth factor and inducible nitric oxide synthase in pterygia. Cornea. 2001;20(7):738-742.

12. Marcovich AL, MoradY, Sandbank J, et al. Angiogenesis in pterygium: morphometric and immunohistochemical study. Curr Eye Res. 2002; 25(1):17-22.

13. Van Setten G, Aspiotis M, BlalockTD, Grotendorst G, Schultz G. Connective tissue growth factor in pterygium: simultaneous presence with vascular endothelial growth factor - possible contributing factor to conjunctival scarring. Grafes Arch Clin Exp Ophthalmol. 2003;241(2):135-139.

14. Yosihada S, Ono M, Shono T, et al. Involvement of interleukin-8, vascular endothelial growth factor, and basic fibroblast growth factor in tumor necrosis factor alpha-dependent angiogenesis. Mol Cell Biol. 1997; 17(7):4015-4023.

15. Pucci N, Novembre E, Ciaferoni A, et al. Efficacy and safety of cyclosporine eyedrops in vernal keratoconjunctivitis. Ann Allergy Asthma Immunol. 2002;89(3):298-303.

16. Strong B, Farley W, Stern ME, Pflugfelder SC. Topical cyclosporine inhibits conjunctival epithelial apoptosis in experimental murine keratoconjunctivitis sicca. Cornea. 2005;24(1):80-85.
17. Al Fayez MF. Limbal versus conjunctival autograft transplantation for advanced and recurrent pterygium. Ophthalmology. 2002;109(9): 1752-1755.

18. Mutlu FM, Sobaci G, Tatar T, Yildirim E. A comparative study of recurrent pterygium surgery: limbal conjunctival autograft transplantation versus mitomycin C with conjunctival flap. Ophthalmology. 1999; 106(4):817-821.

19. Nakamura M, Nishida T. Differential effects of epidermal growth factor and interleukin 6 on corneal epithelial cells and vascular endothelial cells. Cornea. 1999;18(4):452-458.

20. Solomon AS. Immunologic basis for the pathogenesis of pterygium. Am J Optalmol. 1985;99:216-217.

21. Nussenblatt RB, Palestine AG. Cyclosporine: immunology, pharmacology and therapeutic uses. Surv Opthalmol. 1986;31:159-169.

22. Okudaira H, Sakurai Y, Terado K, et al. Cyclosporin A-induced suppression of ongoing IgE antibody formation in the mouse. Int Arch Allergy Appl Immunol. 1986;79:164-181.

23. Hercules LA, Viveiros MM, Schellini SA, Cadeias J, Padovani CR. Exposure of Tenon's capsule fibroblasts of pterygium to cyclosporin 0.05\%. Arg Bras Oftalmol. 2006;(69):831-834.

24. Wu H, Chen G. Cyclosporine A and thiotepa in prevention of postoperative recurrence of pterygium. Yan Ke Xue Bao. 1999;15(2):91-92.

25. Yalcin Tok O, Burcu Nurozler A, Ergun G, Akbas Kocaoglu F, Duman S. Topical cyclosporine A in the prevention of pterygium recurrence. $\mathrm{Oph}$ thalmologica. 2008;222(6):391-396.

26. Aydin A, Karadayi K, Aykan U, Can G, Colakoglu K, Bilge AH Effectiveness of topical ciclosporin A treatment after excision of primary pterygium and limbal conjunctival autograft. J Fr Ophtalmol. 2008; 31(7):699-704.

27. Ibáñez M, Eugarrios MF, Calderón DI. Topical cyclosporin A and mitomycin $\mathrm{C}$ injection as adjunctive therapy for prevention of primary pterygium recurrence. Ophthalmic Surg Lasers Imaging. 2009;40(3): 239-244.
Clinical Ophthalmology

\section{Publish your work in this journal}

Clinical Ophthalmology is an international, peer-reviewed journal covering all subspecialties within ophthalmology. Key topics include: Optometry; Visual science; Pharmacology and drug therapy in eye diseases; Basic Sciences; Primary and Secondary eye care; Patient Safety and Quality of Care Improvements. This journal is indexed on

\section{Dovepress}

PubMed Central and CAS, and is the official journal of The Society of Clinical Ophthalmology (SCO). The manuscript management system is completely online and includes a very quick and fair peer-review system, which is all easy to use. Visit http://www.dovepress.com/ testimonials.php to read real quotes from published authors. 